\title{
Oscar Wilde at Trinity College Dublin*
}

\author{
Sir Edward Sullivan
}

He had rooms in College at the north side of one of the older squares, known as Botany Bay. These rooms were exceedingly grimy and ill-kept. He never entertained there. On the rare occasions when visitors were admitted, an unfinished landscape in oils was always on the easel in a prominent place in his sitting room. He would invariably refer to it, telling one in his humorously unconvincing way that 'he had just put in the butterfly.' Those of us who had seen his work in the drawing class presided over by 'Bully' Wakeman at Portora were not likely to be deceived in the matter. ...

* Boris Brasol, Oscar Wilde: The Man - the Artist, the Martyr (London: William \& Norgate; New York; Charles Scribner's Sons, 1938) p. 31. Editor's title.

\section{NOTE}

In 187 I Oscar Wilde matriculated as a junior freshman at Trinity College Dublin, where he spent three years. His life at Trinity was fraught with no momentous events, and biographical details regarding this period of his growth are indeed scanty. He met there, however, a man who was destined to exercise a signal influence upon his mental orientation. This was the Reverend John Pentland Mahaffy, Precentor and Junior Dean of the College, who became the young lad's tutor and teacher in Greek. Mahaffy initiated his talented pupil into the cult of Hellenic art. Sir Edward Sullivan, Bart., was a schoolfellow of Wilde at Portora Royal School at Enniskillen, which Wilde attended from 1857 to $187 \mathrm{I}$. Sir Edward Sullivan, 2nd Bart., published, among other books, an edition of The Book of Kells in 1918. This was an analysis of the most famous text in the Library of Trinity College Dublin, the university at which Sir Edward had been a contemporary of Wilde's. 